Matematikai Közlemények

IV. kötet, 2017

doi:10.20312/dim.2017.07

\title{
A vakfolt-mentes sarokreflektorok anyagtakarékos kialakítása
}

\author{
Kalmár János \\ Soproni Egyetem, SKK, INGA \\ kalmar@inf.uni-sopron.hu \\ Bányai László \\ MTA CSFK GGI \\ banyai@ggki.hu
}

\begin{abstract}
ÖSSZEFOGLALÓ. Kutatásunkban különböző geometriájú radar sarokreflektorokat vizsgáltunk meg az oldallapok anyagtakarékos kialakítása szempontjából. Monte Carlo modellezéssel és geometriai analízissel kimutattuk, hogy egyes reflektortípusok oldalainak ötöde/harmada lehet vakfolt, ezek elhagyása vagy más célú hasznosítása (pl. a szerkezet merevítésére) nem csökkenti a hasznos tükrözö felületet, vagyis a radarreflektorok anyagköltsége (és súlya) a hatékonyság fenntartása mellett jelentősen csökkenthető.

ABSTRACT. In our research we studied radar corner reflectors with different geometry for the material-saving design of side panels. By Monte Carlo modelling and geometric analysis we have shown that one fifth or third part of the sides of some reflector types may be blind area. Cutting these areas or partly using for stiffening the structure does not reduce the useful reflective surface; so the material cost (and weight) of the radar reflectors can be significantly reduced.
\end{abstract}

\section{Bevezetés}

Egy sík felületről visszaverődő fény/radarsugár az optikai fényvisszaverés törvényét követi, vagyis a sugár beesési és visszaverődési szöge egyenlö, ezért csak a felületre merőlegesen érkező sugár jut vissza a forrásba - napjaink 'lopakodó' jármüveinek alakja emiatt konvex, kis síklapokkal határolt test, aminek radarvisszhangja a hagyományos jármüvekének csak töredéke. Viszont ha a láthatóságot növelni szeretnénk, akkor sarokreflektort érdemes használni, mert abból hármas tükrözés után pontosan a beesési iránnyal ellentétesen lépnek ki/verődnek vissza a radarjelek, így biztosan eljutnak a forrásban elhelyezett detektorba. A sarokreflektor optimális formája három, egymásra merőleges (jó visszaverö anyagból, pl. fémből készült) síkból képzett tükör [2]. Feltétel, hogy a reflektor mérete legyen nagyobb a radarjel hullámhosszánál [3], és legjobb hatásfokát akkor éri el, ha a beeső sugár föirányú, azaz a reflektor középvonalával párhuzamos, mert ekkor lesz a tükrözési keresztmetszet maximális. A légi és vízi közlekedésben azért használnak radarreflektorokat, hogy a hordozó - kisméretű, esetleg nem fémből készült - járművet, bóját, könnyebben felismerhetővé (észrevehetővé) tegyék a többi, környezetét radarral pásztázó jármű számára, ami segít megelőzni az ütközéseket. Ekkor a reflektort bármilyen irányból érheti a radarjel, ezért sarkuknál összeillesztett 8 darab negyedkörös vagy háromszög sarokreflektort alkalmaznak (1. ábra), hogy mindenképpen keletkezzék radarvisszhang. 
Hasonló radarreflektorokat kötelező használni meteorológiai léggömbökön is, hogy a repülőgépek észleljék és kikerülhessék azokat.

\section{Mesterséges radar-reflektorok tervezése és telepítése az ESA programhoz}

Egy ESA PECS támogatásnak köszönhetően a hazai INSAR kutatások központja Sopron lett, itt folyik a Sentinel radar müholdképek geodinamikai alkalmazhatóságának vizsgálata [1]. A természetes felszínborítású területeken sajnos kevés stabil radarreflektor (tükör) található, ezért mesterséges reflektorok telepítésére is szükség van. A különböző időpontokban, de azonos pozíciókból készített felvételek alapján lehetőség van a reflektorok mozgásvizsgálatára. A mérés lényege, hogy a müholdról kisugárzott radarjel visszhangját detektálva a jelerősség (amplitúdó) alapján azonosítjuk a reflektorokat, és két, egymás utáni mérés fáziskülönbségéből következtetünk a reflektor esetleges elmozdulására.

Tekintettel arra, hogy már a reflektor telepítése előtt ismerjük a mühold mérésidejü (közelítö) pozícióját, ezért a reflektort telepítéskor úgy rögzítjük, hogy föiránya (középvonala) az ismert müholdpozíció felé mutasson. Korábbi kutatásunkban [4] már megvizsgáltuk, hogy a sarokreflektorok különböző geometriájú oldallapjai mekkora hasznos tükröző felületet nyújtanak, anyag és hely- takarékosság, illetve merevség szempontjából milyen az oldalak optimális kialakítása. E célból programot készítettünk a reflektorba érkező radarjelek útjának leírására, hogy megállapítsuk, hol vannak az egyes reflektorok 'vakfoltjai', azaz olyan területek, ahová beérkező főirányú radarjel idő előtt - háromnál kevesebb tükrözés után, rossz irányban - lép ki a reflektorból.

\section{Az opto-geometriai modellezés eredményei}

A reflektorba érkező fény/radarjelek Monte-Carlo vizsgálata már előrevetítette, hogy a reflektor alakjától függő vakfoltok valóban elöfordulnak, de ezek pontos alakját/nagyságát csak koordináta-geometriai megfontolások révén tudtuk meghatározni.

Az egyszerüség kedvéért a sarokreflektor csúcspontja az origóba került, oldallapjai pedig az $(x, y),(x, z)$ és $(y, z)$ síkokkal estek egybe. A fénysugár irányvektora legyen $\mathrm{n}_{\mathrm{o}}(-1,-1,-1)$, azaz egybeesik a reflektor föirányával. Tegyük fel, hogy a fénysugár elöször az $(y, z)$ oldallapról verődik vissza, annak $(0, y l, z l)$ pontját érintve. A visszaverődés után a fénysugár

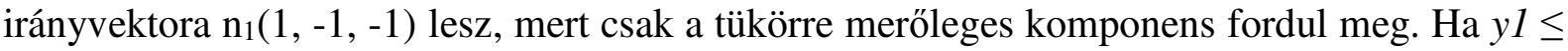
$z 1$, akkor a fénysugár az $(x, z)$ oldallap $(x 2,0, z 2)$ pontjából verődik vissza. Ekkor irányvektorának y komponense fordul meg, és lesz $\mathrm{n}_{2}(1,1,-1)$. A harmadik, $(x, y)$ oldallapon visszatükröződve a kimenő fénysugár irányvektora $\mathrm{n}_{3}(1,1,1)$ lesz, vagyis a beesési iránnyal pont ellentétesen lép ki a sugár a reflektorból a hármas tükrözés után, a harmadik tükörpont pedig $(x 3, y 3,0)$ lesz. A sugár útját követve kiszámítható a második és harmadik tükörpontok helyzete az első függvényében:

$$
\begin{aligned}
& x 2=y 1, y 2=0, z 2=z 1-y 1, \\
& x 3=z 1, y 3=z 1-y 1, z 3=0 .
\end{aligned}
$$

Ha $y l>z l$, akkor az első $(y, z)$ tükrözés után a második tükrözés az $(x, y)$ oldallapon, majd a harmadik tükrözés az $(x, z)$ oldallapon történik, és a tükörpontok helyzete így alakul:

$$
\begin{gathered}
x 2=z 1, y 2=y 1-z 1, z 2=0, \\
x 3=y 1, y 3=0, z 3=y 1-z 1 .
\end{gathered}
$$


Négyzet oldallapú, $b$ él-hosszú sarokreflektornál, ahol $0 \leq y l, z l \leq b$, a tükörpontok (1) és (2) koordinátái alapján nyilvánvaló, hogy teljesülni fognak az $0 \leq x 2, y 2, z 2 \leq b$ és $0 \leq x 3, y 3, z 3 \leq b$ korlátok, vagyis minden, a reflektor $(y, z)$ síkját elérő sugár pontosan három tükröződés után a beesési iránnyal ellentétesen lép ki a reflektorból, tehát ennek a reflektornak nincs vakfoltja.

Az a élhosszú, háromszög alakú sarokreflektor $(0, y l, z 1)$ belső pontjára vonatkozó feltételek az $(y, z)$ oldallapon

$$
0 \leq y 1, z 1 \leq a, y 1+z 1 \leq a .
$$

Természetesen a reflektor $(\mathrm{x}, \mathrm{z})$ és $(\mathrm{x}, \mathrm{y})$ oldallapjai is háromszögre csonkítottak, tehát teljesülnie kell $0 \leq x 2, z 2, x 3, y 3 \leq a$ mellett az

$$
\begin{aligned}
& x 2+z 2 \leq a \\
& x 3+y 3 \leq a
\end{aligned}
$$

feltételeknek is. A (4) és (5) feltételek (1) alapján visszavezethetők az (y,z) síkra:

$$
\begin{gathered}
z 1 \leq a, \\
2 z 1-y 1 \leq a .
\end{gathered}
$$

A (6) feltétel (3) miatt mindig teljesül, (7) és (3) pedig vakfolttá minősíti az (y,z) síknak az alábbi pontok által kifeszített háromszögét: $(0,0, a),(0,0, a / 2),(0, a / 3,2 a / 3)$.

Ha $y 1>z 1$, akkor hasonló gondolatmenettel (2) tükörpont egyenletekböl indulva kapjuk a másik vakfolt háromszögét, melyet a 2 . ábrán láthatóan a következő pontok feszítenek ki az $(y, z)$ síkon: $(0, a, 0),(0,2 a / 3, a / 3),(0, a / 2,0)$.

A harmadik vizsgált reflektortípus az egységnyi sugarú, origó középpontú negyed körökből álló sarokreflektor, ahol $0 \leq y 1, z 1 \leq 1$ mellett teljesül a

$$
y 1^{2}+z 1^{2} \leq 1
$$

feltétel is. Természetesen a reflektor $(x, z)$ és $(x, y)$ oldallapjai is negyed körre csonkítottak, ezért $0 \leq x 2, z 2, x 3, y 3 \leq 1$ mellett teljesülnie kell az

$$
\begin{aligned}
& x 2^{2}+z 2^{2} \leq 1 \\
& x 3^{2}+y 3^{2} \leq 1
\end{aligned}
$$

feltételeknek is. A (9) és (10) feltételek (1) miatt most is kifejezhetők az $(y 1, z 1)$ koordinátákkal:

$$
\begin{aligned}
& y l^{2}+(z l-y l)^{2} \leq 1 \\
& z l^{2}+(z l-y l)^{2} \leq 1
\end{aligned}
$$

A (11) feltételből a korábbiaknál szigorúbb új korlát vezethető le:

$$
z 1 \geq y 1-\sqrt{ }\left(1-y 1^{2}\right)
$$

melynek értelmezési tartománya $1 / \sqrt{ } 2 \leq y 1 \leq 2 / \sqrt{ } 5$.

A (12) feltételből az alábbi korlát vezethetö le:

$$
z 1 \leq\left(y 1+\sqrt{ }\left(2-y 1^{2}\right)\right) / 2
$$

melynek értelmezési tartománya $0 \leq y 1 \leq 1 / \sqrt{ } 5$. 
Ha $y l>z l$, akkor (2) alapján (9) és (10) feltételek így írhatók fel az $(y 1, z l)$ koordinátákkal:

$$
\begin{aligned}
& z l^{2}+(y 1-z l)^{2} \leq 1 \\
& y l^{2}+(y 1-z l)^{2} \leq 1
\end{aligned}
$$

Látható, hogy (15) ekvivalens (11)-el, (16) pedig (12)-vel, vagyis a korlátok (a mértani helyek) nem változnak. A (8) feltétel átírható

$$
z 1 \leq \sqrt{ }\left(1-y 1^{2}\right)
$$

alakba, és a képlet értelmezési tartománya $1 / \sqrt{ } 5 \leq y 1 \leq 2 / \sqrt{ } 5$ lesz.
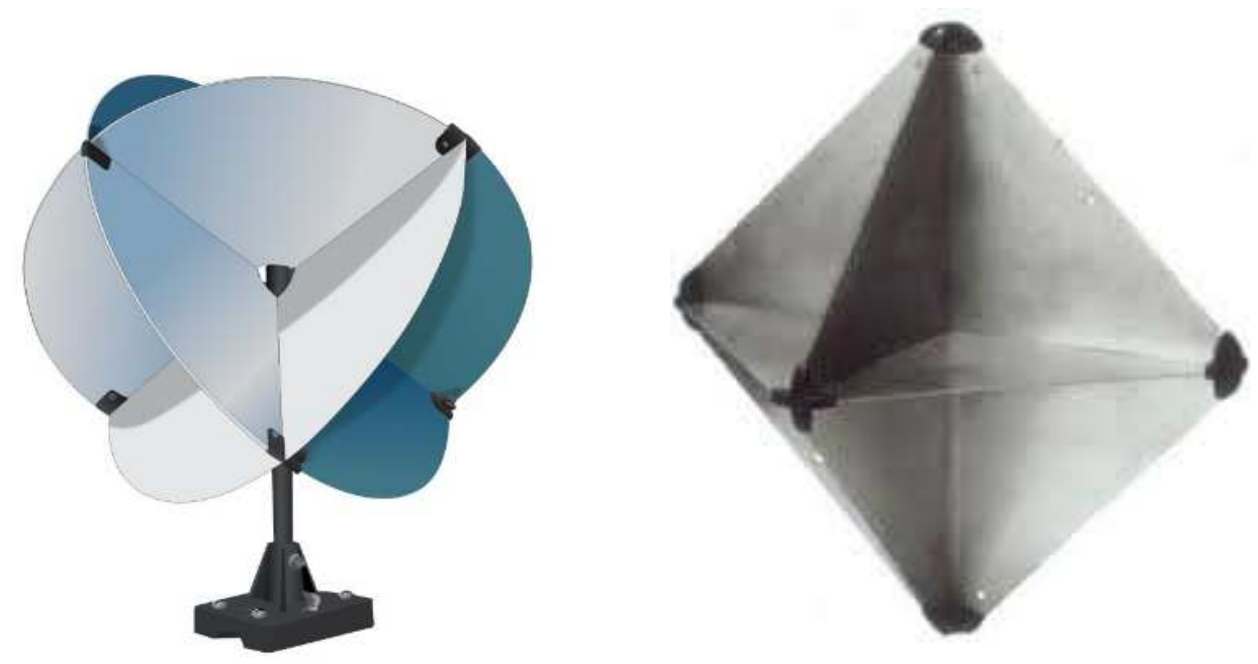

1. ábra. Irányítatlan radar-reflektorok

\section{4. Összefoglaló}

Modellezési és geometriai vizsgálataink szerint a vakfoltok elhagyása nem csökkenti a reflektor hatékonyságát (hasznos radarkeresztmetszetét), csökkenti viszont súlyát és anyagköltségét. A sarokreflektorokba a föirányból érkező radarjelek opto-geometriai modellezése az alábbi megállapításokkal zárult:

A négyzet oldallapú sarokreflektoron vakfoltot nem találtunk, vagyis ha egy fénysugár bárhol eléri a reflektort, akkor a hármas tükrözés után biztosan visszaverődik a forrás irányába.

Háromszög lapokból álló, a él-hosszú sarokreflektor esetén - csúcspontjai a $\{(0,0),(a$, $0),(0, a)\}$ pontok - a lapok vakfoltjai (az oda beérkező sugár rossz irányba verődik vissza) a $\{(a / 2,0),(a, 0),(2 a / 3, a / 3)\}$ és $\{(0, a / 2),(0, a),(a / 3,2 a / 3)\}$ pontok által alkotott háromszögek (2. ábra). A vakfoltok területe az eredeti háromszög-lap területének harmada. A kontúrélek pontos egyenletei az $(y, z)$ síkon (oldallapon) alább láthatók:

$$
\begin{array}{ll}
z=(a+y) / 2, & \text { ha } 0 \leq y \leq a / 3, \\
z=a-y, & \text { ha } a / 3 \leq y \leq 2 a / 3, \\
z=2 y-a, & \text { ha } a / 2 \leq y \leq 2 a / 3 .
\end{array}
$$

Az egységnyi $(1 \mathrm{~m})$ sugarú, origó középpontú negyed körökből álló sarokreflektor vakfoltjait az $\{(1 / \sqrt{ } 2,0),(2 / \sqrt{5}, 1 / \sqrt{ } 5)\}$ és $\{(0,1 / \sqrt{ } 2),(1 / \sqrt{ } 5,2 / \sqrt{ } 5)\}$ pontpárok közötti ellipszis 
ívek határolják (3. ábra). A vakfoltok a negyed kör területének 18\%-át teszik ki. A kontúr élek egyenletei alább láthatók:

$$
\begin{array}{ll}
z=\left(y+\sqrt{ }\left(2-y^{2}\right)\right) 2, & \text { ha } 0 \leq y \leq 1 / \sqrt{ } 5 \\
z=\sqrt{ }\left(1-y^{2}\right), & \text { ha } 1 / \sqrt{5} \leq y \leq 2 / \sqrt{ } 5 \\
z=y-\sqrt{ }\left(1-y^{2}\right), & \text { ha } 1 / \sqrt{ } 2 \leq y \leq 2 / \sqrt{ } 5
\end{array}
$$

Ha azt szeretnénk elérni, hogy a háromszög oldallapú sarokreflektornak ugyanakkora hasznos radarkeresztmetszete legyen, mint az egységsugarú negyedkörös sarokreflektornak, akkor a sarokreflektor él-hosszát $a=1,38942$ m-ben kell rögzíteni (4. ábra).

Ha azt szeretnénk elérni, hogy a négyzet oldallapú sarokreflektornak ugyanakkora hasznos radarkeresztmetszete legyen, mint az egységsugarú negyedkörös sarokreflektornak, akkor oldalhosszát $b=0,8021852$ m-ben kell rögzíteni (4. ábra).

A négyzet oldallapú sarokreflektor oldallapjának legnagyobb kiterjedése (2 belső pontjának legnagyobb távolsága) 1,13446 m, a háromszög oldallapué (4. ábra) 1,0356 m, a negyed kör oldallapúé pedig $1 \mathrm{~m}$.

Az egyforma hasznos radar-keresztmetszetü sarokreflektorok széleinek merevítéséhez szükséges keretek összhosszai - pl. a négyzet oldallapú sarokreflektornál ez $9 b$ - csak 1\%-al térnek el egymástól.

A Monte-Carlo modellezés alátámasztotta azon sejtésünket, hogy a sarokreflektornak van fázis centruma, és az a reflektor sarokpontjában - ahol a három, egymásra merőleges sík találkozik - van, tehát bármely, a reflektorból hármas tükrözés után visszaverődő fény/radarsugár pontosan akkora utat tesz meg, mintha a fáziscentrumból verődne vissza.

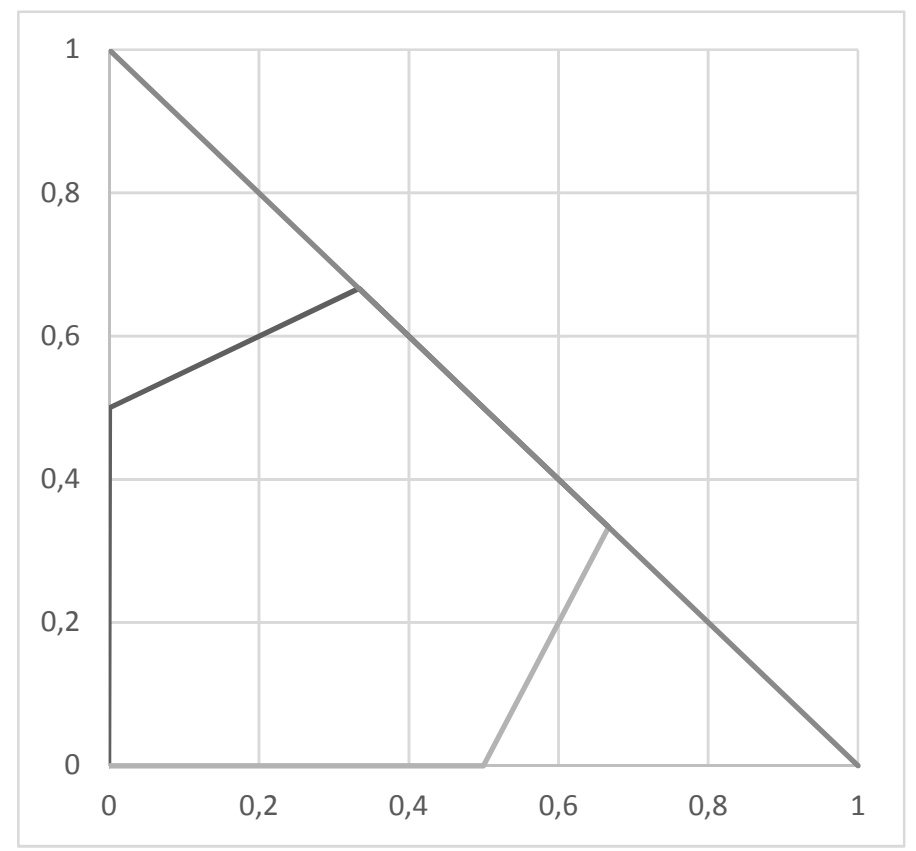

2. ábra. Egységnyi él-hosszú háromszög sarokreflektor hasznos felülete 


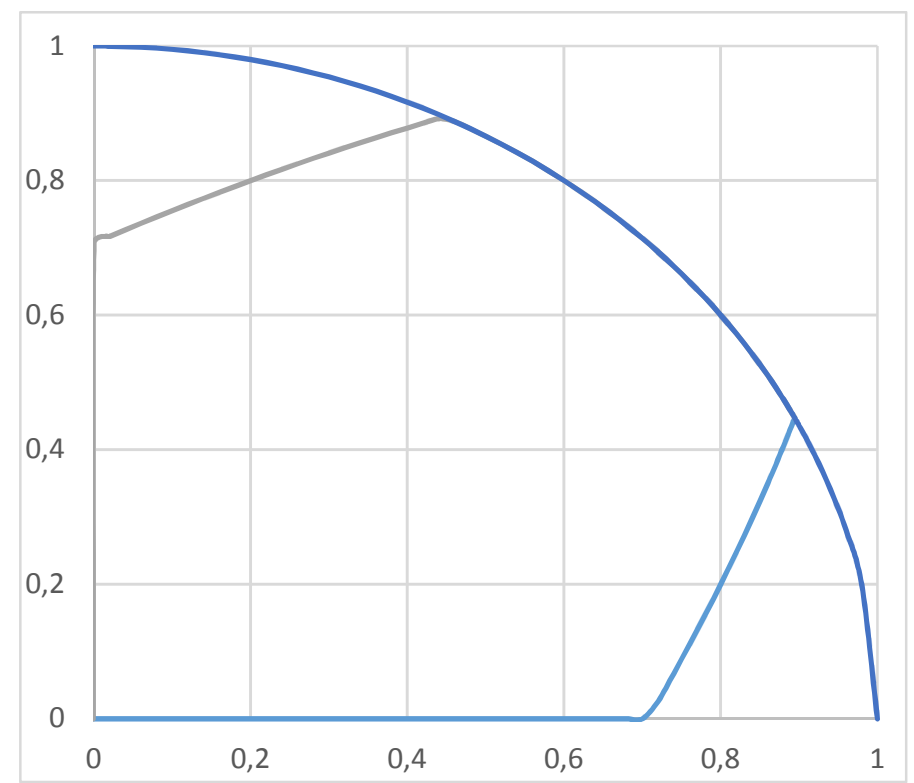

3. ábra. Egységnyi sugarú negyed-kör sarokreflektor hasznos felülete

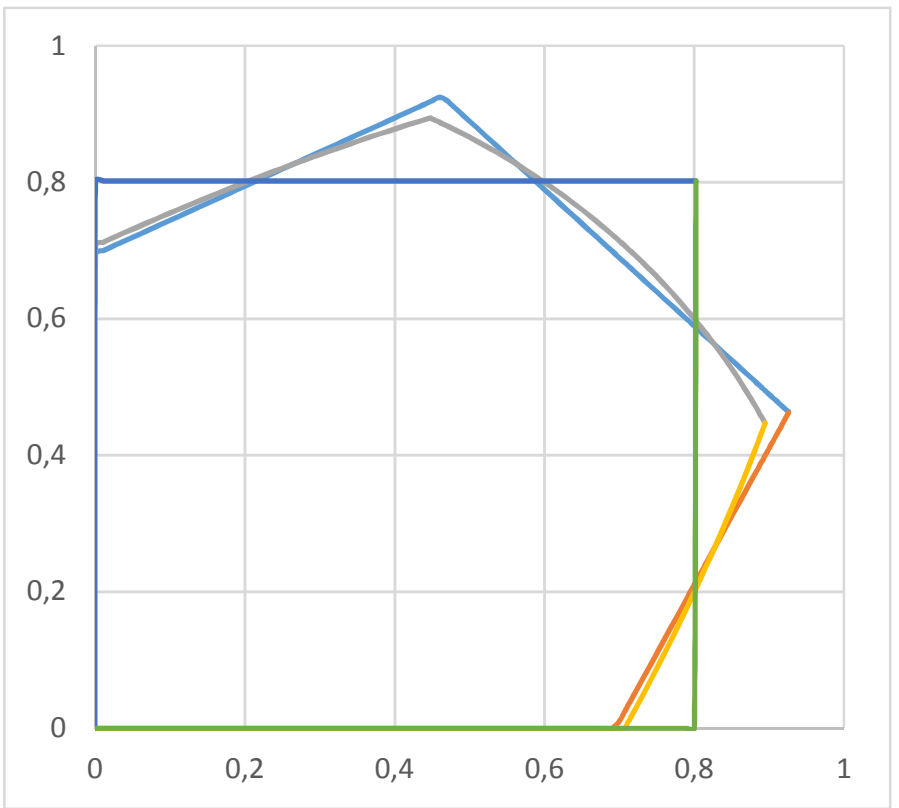

4. ábra. Azonos hasznos felületü sarokreflektorok oldallapjai

\section{Irodalomjegyzék}

[1] Bányai L., Szücs E., Kalmár J., Eperné Pápai I., Bán D., Az INSAR technológia alapjai és a reflektáló felületek jellemzöi, Geomatikai Közlemények 17, (2014), 59-68.

[2] Newman, W. I., Continuum Mechanics in the Earth Sciences. Cambridge University Press, (2012), 6-7. doi:10.1017/CBO9780511980121.

[3] Kraus, J., Marhefka, R., Antennas for All Applications, 3rd ed. Mc Graw Hill. p. 365, 2002.

[4] Kalmár J., Bányai L., A mesterséges radar sarokreflektorok geometriailag optimális kialakítása, Magyar Ürkutatási Fórum, Sopron, 04.06, 2017. 